\title{
QUEEN'S
UNIVERSITY
BELFAST
}

\section{The Politics of Brewing Legal Times: Reflections on Emily Grabham, Brewing Legal Times: Things, Form, and the Enactment of Law}

(Toronto: University of Toronto Press, 2016)

McNeilly, K. (2018). The Politics of Brewing Legal Times: Reflections on Emily Grabham, Brewing Legal Times: Things, Form, and the Enactment of Law (Toronto: University of Toronto Press, 2016). Feminist Legal Studies, 26(3), 371-375. https://doi.org/10.1007/s10691-018-9388-x

Published in:

Feminist Legal Studies

Document Version:

Peer reviewed version

Queen's University Belfast - Research Portal:

Link to publication record in Queen's University Belfast Research Portal

Publisher rights

() 2018 Springer Science+Business Media B.V.

This work is made available online in accordance with the publisher's policies. Please refer to any applicable terms of use of the publisher.

\section{General rights}

Copyright for the publications made accessible via the Queen's University Belfast Research Portal is retained by the author(s) and / or other copyright owners and it is a condition of accessing these publications that users recognise and abide by the legal requirements associated with these rights.

Take down policy

The Research Portal is Queen's institutional repository that provides access to Queen's research output. Every effort has been made to ensure that content in the Research Portal does not infringe any person's rights, or applicable UK laws. If you discover content in the

Research Portal that you believe breaches copyright or violates any law, please contact openaccess@qub.ac.uk. 


\title{
The Politics of Brewing Legal Times: Reflections on Emily Grabham, Brewing Legal Times: Things, Form, and the Enactment of Law (Toronto: University of Toronto Press, 2016)
}

\author{
Kathryn McNeilly ${ }^{1}$
}

A substantial amount has been written on the relationship between law and time (Engel 1987; French 2001; Tur 2002; Khan 2009; Mawani 2015). An important subsection of this work has been instructive in moving beyond understanding law as operating against the backdrop of time apprehended as a natural construct, to understanding law and legal processes as themselves creating time (for example, Greenhouse 1989, 1996). Law, in this view, emerges as a central influence shaping our socio-political experience of time in everyday life. In Brewing Legal Times, Emily Grabham makes a significant contribution to this literature informed by interdisciplinary and, specifically, feminist resources. ${ }^{2}$ The unique way in which Grabham does so is to "argue that our relationship with "things" creates legal time' (2016: 6).

Intimately informed by her personal experience of legal practice, Grabham takes her reader on an illuminating, and pathfinding, journey exploring the connection between people, things and law. In doing so, Grabham exposes what she terms the 'thingness' of legal time (2016: 11). She highlights the way in which this time is specific and mundane, arising in and through the collaboration of humans and 'things', objects or other non-human actors. Through a selection of case studies - the concepts of progression and likelihood in UK and Canadian HIV-related non-discrimination and welfare law; transition in UK gender recognition law; and balance in UK laws relating to work-life-balance Grabham skilfully brings into view the 'things' which assist in the construction of legal temporalities. These include tests, medical reports, classification systems, statutory declaration forms, flexible work request forms, vehicles, telephones, and drugs. Mapping the places, locations and contexts where these objects interact with human actors, she draws our attention to the materialisation of law and urges us to understand legal processes as, drawing from Bruno Latour and Michel Serres, 'brewing time' (Grabham 2016: 12-15).

However, Grabham does not seek to merely observe and report on how legal temporalities in their diverse and often humdrum form are constructed as a way to better understand law. Or, more accurately, she does not seek to do this alone. Rather, informed by thinking on the politics of engagement with time (Grosz 1999; Henare, Holbraad and Wastell 2007), Grabham's analysis has a distinctively political purpose. As she states, 'if we understand that our legal actions, arguments, documents and so on have temporalizing effects and do not merely exist "in time", we can also understand those temporalities, things and effects as inherently political because they are worldmaking and not merely passive' (Grabham 2016: 15). She continues that, in this respect, 'by denaturalising the temporalities that co-produce legal norms, by engaging in the process of analysing and making time, we encounter and remake questions of justice over and over again' (Grabham 2016: 15). This is a crucially important part of Grabham's work. Her case studies of HIV-related welfare and discrimination claims, gender recognition, and struggles for work-life balance are not selected at random. These issues are connected by questions of justice, equality, emancipation, radical gender politics and a concern with how these ideas are engaged in law and legal processes.

It is this political element to the 'thingness' of legal time which I would like to focus on and tease out a little more in my reflections on Brewing Leal Times. Reading Grabham's work I found this to hold

\footnotetext{
${ }^{1}$ Lecturer, School of Law, Queen's University Belfast, k.mcneilly@qub.ac.uk.

${ }^{2}$ Graham of course contributes to other bodies of work as well. Of note amongst these is scholarship theorising materiality and the material in law.
} 
much emancipatory potential and wondered whether this aspect to the brewing of legal time could be expanded further. Might it be possible to not only expose the 'thingness' of law, its construction of multiple realities and the questions of justice that this raises, but to encourage radical political actors and groups to use this insight to stage new interventions with legal time? In other words, can we build on making visible the brewing of legal temporality that an object-aware approach facilitates and begin to act on this to generate alternative temporal ideas more amenable to just ends? I suggest that radical actors and movements may consider the strategies that they might employ to do so, and may reflect on how the focus on 'things' that Grabham alerts us to holds potential to translate into politico-legal action to bring into being temporalities which resist the dominant, or trouble it in some way. If human actors are important, but not central, as Grabham argues, we must consider the impact this may have on strategizing in and through legal domains.

In contemplating this, my thoughts turned to the area of law with which I engage most regularly: international human rights law. While operating via different structures and at a different level than the domestic examples found in Grabham's writing, this legal system can also be apprehended as characterised by a distinct 'thing-ness' in its creation of legal time. In international human rights law objects like official reports, lists of recommendations, data, audio-visual evidence, interview transcripts, computers and other technology play a role alongside human actors in creating various co-existing temporalities. For example, a report might generate a sense of urgency, or non-urgency regarding an alleged rights violation; technology might create a pace of time previously unknown in international human rights law; data may effect a pause or disruption of time in holding states to account for their international obligations. Thus, collaborative relationships between human and nonhuman actors generating particular temporal logics are easily identifiable in this area of law also.

Sometimes these relationships create temporalities which are productive for radical political ends. Audio-visual evidence helping to produce a sense of urgency around a violation, and data effecting a disruption of time to create a sense of pause and focus on an emerging issue are two examples. On other occasions, the outcomes of these collaborative relationships may be less amenable to radical ends. Reports or data stimulating non-urgency, placating that human rights violations are not as bad as they may seem, offer one example. Lists of recommendations for states to address that continue a cyclical rhythm which merely prolongs consideration of a human rights issue until the next review cycle offer another. It may be possible, however, for radical actors and groups to question where humans and objects might be brought into collaborative work on the same rights-based issues in alternative ways which disrupt these less than radical rhythms of time, and direct strategic energy in these places. This means seeking to identify the spaces, locations and contexts where humans and things can come together to best maximise the ability to create temporalities which are more amenable to radical or more just ends.

To demonstrate what I mean, one strategic location that may be considered is international human rights law monitoring practices which hold states accountable for their rights obligations. Monitoring takes the form of cyclical processes whereby states are examined every number of years in a regular manner, and irregular one-off review processes triggered by a particular human rights concern being raised. These latter processes in particular offer an innovative space where humans and objects may create new, more emancipatory temporal logics together. One recent example of this can be observed in the context of feminist politics in Northern Ireland where the Convention on the Elimination of All Forms of Discrimination Against Women (CEDAW) Optional Protocol procedure was engaged. Responding to a submission by local feminist NGOs alleging that the restrictive framework for abortion in Northern Ireland results in grave and systematic violation of rights (FPANI, Alliance for Choice and NIWEP 2010), in 2016 the CEDAW Committee carried out an investigation. A number of non-human 
'things' were central in this process, not all of which had been involved in consideration of this issue in international human rights law before. This included interview transcripts with politicians, lawyers, women and stakeholders; data on abortions provided in Northern Ireland and on women who travel abroad; leaflets and advertising material on sexual and reproductive health services; maps of where reproductive health services were available; and guidance documents for health care professionals. While abortion access in this jurisdiction had been noted in regular monitoring by CEDAW and other United Nations Committees from the 1990s onwards, this had come to be routine and created a cyclical temporal rhythm around this issue. In the Optional Protocol investigation, the objects above and the NGO-led allegations combined created a new urgency around access to abortion in this jurisdiction. Reporting in 2018, the Committee found that grave and systemic violations of rights were taking place, and that such must be addressed as a matter of priority (United Nations CEDAW 2018). This served to disrupt cyclicality and generate an alternative temporal rhythm of urgency which has contributed to newly emerging engagement with abortion as a human rights issue in Northern Ireland.

Reading this example through the framework that Grabham provides allows us to see how radical movements and actors may usefully become more aware of where and how relations between humans and 'things' might be encouraged which create differing legal temporalities. This work stays with the specific, the mundane and the humdrum, and is the kind of expansion and strategic capitalisation on Grabham's insightful observations of the brewing of legal time which I was thinking of. Fresh political opportunities may emerge by considering how alternative temporal arrangements might be generated, looking to creative legal locations and means to bring humans and objects into relation anew. While of course I am not arguing that complete human agency is possible in controlling objects or the outcome of these collaborative networks - Grabham makes clear that this is not the case (2016: 26-29) - I am suggesting that a more thoughtful approach to the connection between people, things and law may provide new opportunities for political interventions and strategizing, or make it possible to revisit existing strategies through new lenses.

Grabham's work, as a new tool in thinking about law, time and its politics, helps us to begin to grapple with the relationship between people, things and law in an innovative way not fully articulated in legal scholarship to date. Brewing Legal Times is a significant piece of work offering observations which contribute not only to consideration of time and law, or materiality and law, but bringing these issues together in a manner which is attentive to questions of justice. It is in this respect that I argue one follow-on aspect of Grabham's work may be developing her insights to provide the first steps in conscious approaches to the brewing of legal time in radical politics which are grounded in the everyday reality of law as a practice involving human and non-human actors. This is of course only one way in which the insights this book provides may be taken further. Grabham's work is exciting, it matters in both senses of the word, and it stands as a landmark in legal scholarship on time to be built upon in ongoing activity to understand the temporal life of law more fully. 


\section{References}

Engel, David, 'Law, Time, and Community' Law \& Society Review 21(4) (1987): 605-638.

FPANI, Alliance for Choice and NIWEP, Submission of Evidence to the CEDAW Committee Optional Protocol Inquiry Procedure (Belfast: FPANI, 2010).

French, Rebecca, 'Time in Law' University of Colorado Law Review 72(3) (2001): 663-748.

Grabham, Emily, Brewing Legal Times: Things, Form and the Enactment of Law (Toronto: University of Toronto Press, 2016).

Greenhouse, Carol, 'Just in Time: Temporality and the Cultural Legitimation of Law' The Yale Law Journal 98(8) (1989): 1631-1651.

Greenhouse, Carol, A Moment's Notice: Time Politics Across Cultures (Ithaca, NY: Cornell University Press, 1996).

Grosz, Elizabeth, Becomings: Explorations in Time, Memory, and Futures (Ithaca, NY: Cornell University Press, 1999).

Henare, Amiria J.M, Martin Holbraad and Sai Wastell (eds), Thinking Through Things: Theorising Artefacts Ethnographically (London: Routledge, 2007).

Khan, Liaquat Ali, 'Temporality of Law' McGeorge Law Review 40(1) (2009): 55-106.

Mawani, Renisa, 'The Times of Law' Law \& Social Enquiry 40(1) (2015): 253-263.

Tur, Richard, 'Time and Law' Oxford Journal of Legal Studies 22(3) (2002): 463-488.

United Nations Committee on the Elimination of All Forms of Discrimination Against Women, Report of the inquiry concerning the United Kingdom of Great Britain and Northern Ireland under article 8 of the Optional Protocol to the Convention on the Elimination of All Forms of Discrimination against Women (Geneva: United Nations, 2018). 